\title{
3 パソコンを用いた人工呼吸器点検について
}

東條圭一, 廣瀬 稔 (北里大病院MEセンタ一部)

渡辺 敏 (北里大病院MEセンター部・北里大麻酔科)

近年, 医用工学の進歩により, 多種多様の医療機器 が臨休の場飞導入されている。そして，院内における 人工呼吸器や IABP 装置などの生命維持管理装置の保 守点検は，我々臨床工学技士が行っている．それら点 検業務のうち, 故障症状の再現性の無いるのや動作の 安全性を見る場合には，動作状況を長時間にわたって 監視する必要があるが，限られた業務時間内他の業 務の傍ら動作状況を確認しているのが現状である。

そこで今回我々は, 人工呼吸器を対象に, 昨年 6 月 日本医科器械学会臨床工学研究会で発表したパソコン による医療機器の保守管理システムに改良を加兄, 機 器より直接得られる情報之点検用測定器から得られる 情報とを，パソコンに取り込み，その作動状況を長時 間，自動的連続的に監視するシステムを試作したので 報告する.

[システムの概略]今回点検に使用したシステム
は，人工呼吸器の動作監視にタイメータ社製 R T-200 キャリブレーションアナライザを使用し，そのアナロ グ出力と人工呼吸器からのアナログ出力を, A-D 変 換器カノープス社製 ANALOG-PROjr に入力しデジ タル信号にてハーソナルコンピュータ PC-9801 n K 取り込むようにした．点検プログラムは自作のものを 使用し, 点検結果の検索方法や操作性について改良を 加光た，監視中，異常動作が発生した場合には，その 作動状況をフロッピーディスクに保存するようにし た.

[使用経験]このシステムを使用した結果, 長時間 にわたる人工呼吸器の作動状況確認が他の業務の傍ら 連続して行うことができ，かつ，システムの操作性が 向上し, 人工呼吸器の保守管理に有用であることがわ かった. 今後, さらに改良を加光, 多くの医用機器に ついても同様のシステムを製作したいと考学る。

\section{ALL-In-One PCPS 装置の開発}

河村剛史, 樋上哲哉, 小川恭一（兵庫県立姫路循環器病センター心臓血管外科） 福井康裕（東京電機大応用電子工学科）

舟久保昭夫 (職業能力開発大学校福祉工学科)

経皮的心肺補助装置 (Percutaneous Cardio-pulmonary Support, 以下 PCPS) は，その簡易性から DOA (Dead On Arrival) 患者, PTCA 不成功例の 心停止患者などの緊急循環補助のみならず, IABP 無 効の重症の心筋炎患者や心筋梗塞患者の心源性 ショッ クに対する上位補助循環として使用されている．特に この中で PTCA 施行時の心停止患者は緊急冠動脈バ イパス手術開始をでの “つなぎ”として PCPS 挿入 が非常に有効な手段となる. 今回, PCPS の緊急性, 補助流量限界, 緊急搬送など考虑に入れたポンプと膜 型人工肺とが一体となった All-In-One PCPS 装置を 考案した。

[方法] All-In-One PCPS 装置についての基本設 計思想として, “on the bed, near the patient” 念頭に置き, 患者の股間に置けるコンパクトな装置を 考光た。最大補助流量 $41 / \mathrm{min}$ 飞至適な, かつ 2 重円 筒型膜型肺（エクセラン）と一体化 (All-In-One) で
きる形状の遠心ポンプの開発を行った。開発した心肺 部 All-In-One は, 外径 $90 \mathrm{~mm}$, 長さ $250 \mathrm{~mm}$, 重 量 $1 \mathrm{~kg}$ で, 血液充填量は $250 \mathrm{ml}$ となり, 血液回路 を含めて $300 \mathrm{ml}$ 程度にすることができた。

雑種成犬を用いて，心筋梗塞作成後江電気的飞心室 細動を起こし本装置の有用性を検討した。

[結果拉よび結論】 心室細動下に执いては, 右房压 の低下に反して，左房圧は低下せず左心系の減圧は得 られなかった．この状態では電気的除細動は効果がな く, 心マッサージによる一時的左室内の減圧後に除細 動ができた。

このことから，DOA 患者に対する緊急 PCPS 装 着時, 脳潅流維持には有効であるが, 有効な流量が得 られても左心系の減圧効果は期待できず，有効な除細 動状態を得るためには PCPS 装着後においても心マッ サージを続けて拉く必要がある。 